\title{
THE VISUAL ARTIST IN PRIME TIME TELEVSION
}

\section{Roy Pearson}

\section{Introduction}

Since the 1940s, audiences have accepted and assimilated the powers and exploits of television characters. As early as 1941

President Roosevelt transferred his fireside radio chats to the visual medium of television. In the same year the Federal Communications Commission began to expand beyond the existent 5,000 television sets to make home television viewing as common as radio (DeFleur, 1966). Early television characters such as Red Skelton, Dick Gregory, and Gale Storm, as well as Superman, Wonder Woman, and Fat Albert, began to regularly supply television audiences with knowledge about behavioral models that many viewers continue to mimic today. The notion that television characters do influence viewer behaviors was postulated through The Cultural Norms Theory. The theory states that the medium provides a "definition of a situation" which the actor believes to be real. This definition provides guides for action which appear to be approved and supported by society (DeFleur, 1966, p. 130).

Television's use of advanced technical and production techniques developed in the 1960s and 1970s now creates the appearance of verisimilitude in all types of characters. Content differences in contemporary television, bringing a greater variety of formats, a greater variety of characters, and fuller character development, have grown out of audience studies that indicate a desire for verisimilitude. Apart from their general similarities of ethnicity, occupation, sex, and age, however, research indicates that TV characters are routinely and significantly different from their real life counterparts (Greenberg, Simmons, Hogan, and Atkin, 1980, p. 35). 
Television doctors, lawyers, police, architects, ranchers, and artists all display characteristics that make their real life counterparts appear colorless and vapid (deFleur and Dennis, 1981, p. 345). The purpose of this investigation is threefold: first, to make apparent that the artist is frequently portrayed in American prime time television; second, to critically describe, interpret, and evaluate how artists are portrayed; and third, to consider possible effects of television's portrayals of artists and the teaching of art.

\section{Television and the Audience}

For unsuspecting viewers television is a comparative norm against which they gauge their lives and the lives of others. Gross (1974) states:

... the basic topography of television offers to the unsuspecting viewer a continuous stream of "facts" and impressions. The premise of realism is a Trojan Horse which carries a highly selective and purposeful image of reality. (p.86)

Scores of scholars studying television from several perspectives provide evidence supporting the hypothesis that people's beliefs about the world are significantly influenced by how the world is portrayed on television; Baggaley (1980), Berger (1976) and (1980), Becker (1982), DeFleur and Dennis (1981), Dorr (1986), Gans (1970), Hiebert and Reuss (1985), Mander (1977), Novak (1982), and Real (1977) are typical examples.

Such implications are cause for educational concern if we accept the research. No other form of visual communication is, or ever has been, as pervasive as television. It is seen daily, consuming large blocks of time for the average American. Current estimates are that only two percent of the American population is without television (Nielsen, 1985). The medium's programming crosses nearly every social, political, and economic population barrier in the country, 
leading some experts to call television the common denominator for shared experiences (Charren and Sandler, 1983). A once popular notion that television only influenced the lower socioeconomic strata of the population has been supplanted. There is considerable evidence that America's professionals and educated elite watch the same situation comedies and action adventures as their blue collar counterparts (Wilensky, 1964). Says one of television's critics, "America's media managers create, process, refine, and preside over the circulation of images and information which determine our beliefs and attitudes and, ultimately our behavior" (Schiller, 1973 p. 1). To regard television passively or as a mere source of entertainment is to underestimate its impact on the viewer.

\section{The Artist and Television}

It has been suggested by Lanier (1968, 1982), Feldman (1982), and others that an all inclusive, or even adequate, singular definition of the visual artist is cognitively inadequate, socially narrow, and intellectually boring. Making a determination about who would be included as an artist in this research is based on the thinking of Lanier and Feldman. Lanier's (1982) conceptual taxonomy includes individuals working in folk arts, popular arts, practical arts, and expressive arts. In addition, Feldman's (1982) "Hyphenated Artist" concept broadens the scope of the artist-person to include dentist-artists, or teacher-artists. The hyphenation, insists Feldman (1982), does not imply that these artists are aesthetically deficient or technically inferior. It simply means that "today's artist is not always a full time artist" (p. 201). This additional criterion assures comprehensive inclusion of artist character portrayals for this study.

The Artist in Prime Time

Several weekly programs include portrayals of visual artists. 
Commercial programs using an entertainment format are more likely to present the character of the artist with a greater breadth of emotive hues than non-commerical formats (Lanier, 1968, p. 2). The majority of characters to be examined in prime time network programs in this research may be portrayed in primary, secondary, or referential roles.

Several weekly shows during the 1985-86 season portrayed artists in primary roles. "Cover Up," a detective drama on the CBS network, portrayed a professional fashion photographer as its central figure. The artist was depicted as a free-lance magazine photographer who shot high fashion designs around the world. Another CBS program and situation comedy, "My Sister Sam," also starred a woman as a commerical photographer living in San Francisco.

Artists in secondary roles are the most common. They generally offer supporting roles for the actions of stars. "Hill Street Blues," "Miami Vice," "Amazing Stories," "Moonlighting," "Magnum," "Family Ties," and "St. Elsewhere" have all used the visual artist as a secondary character. On occasion a program such as one of the aforementioned will include the artist in episodic plots that carry over to additional episodes. Artists as secondary characters, however, are usually part of single events within overall plots. They tend to be used as connotative symbols with little character or professional development. Less frequently, a real life artist will appear in prime time programming as a secondary character. Andy Warhol, for example, appeared in "The Love Boat."

A third representation of the artist, quite apart from the ones mentioned, is by reference. These portrayals may appear as rapid or passive visual images or they may be developed through dialogue. Such references have occurred on "Kate and Allie," "Crime Story," "Newhart," and "Downtown." An episode of "Kate and Allie" established an arrest scene in which a conversation about mug shots included mention of the photographs of Diane Arbus. Several television commercials have also made reference to artists for specific 
associations with products: Leonardo Da Vinci and Bruce Newman with copy machines and Claus Oldenburg with Jello-Pops.

\section{Method}

The research method in this study is an application of the concept of "artistic criticism" as identified by Hospers (1982). Hospers divides artistic criticism into two major types, descriptive/interpretive and evaluative. He understands the descriptive/interpretive type to be a means of gaining a greater understanding and perhaps a condition toward a more meaningful appreciation of works of art. He understands the evaluative type as an end; an intelligent way to access "verdicts" (p. 302) based on the quality of the work. Television, like all art forms, expresses a range of qualities requiring intelligent verdicts.

The critical examination of this study will focus solely on programming content within prime time network television, especially the portrayal of visual artists. Individual programs will be selected that represent each genre in prime time to determine if, how, and under what circumstances an artist is portrayed in that program. This researcher observed and sampled all the varieties of programming genre during a season of prime time television and determined which were appropriate to this study. To establish common nomenclature, Rose's (1985) ten genres were slected: The Police Show, The Detective Show, The TV Western, Medical Melodrama, Science Fiction and Fantasy, Situation Comedy, The Soap Opera, Television Documentary, The Variety Show, and The Television Commercial. Each genre is also seen in several programs in the course of the 24 week television season.

Rationale for implementation of artistic criticism in this study was simply and effectively stated by Hospers: "to make the work intelligible to us, to help us see the things in it we failed to see before, or to put the things we did see into a new pattern or perspective" (p. 297). With this critical method the goal of this 
research is to determine the obvious and implied meanings of such portrayals and to postulate the possible effects such portrayals of the artists may have on the public's attitudes about artists and the teaching of art in the schools.

\section{References}

Becker, H. (1982). Art worlds. Berkeley, C A: University of California Press.

Berger, A. (1976). The TV guided American. Radnor, Penn: Walker Publishing Company, Inc.

Berger, A. (1980). Television as an instrument of terror. New

Brunswick, N J: Transaction Books.

Charren, P. and Sandler, M. (1983). Changing channels. Reading MA:

Addison-Wesley Publishing Company.

DeFleur, M. (1966). Theories of mass communication. New York: David McKay Company, Inc.

DeFleur, M. and Dennis, E. (1981). Understanding mass communication. Boston: Houghton Mifflin Company.

Dorr, A. (1986). Television and children. Beverly Hills: Sage Publications.

Feldman, E. (1982). The artist. Englewood Cliffs: Prentice-Hall. Friendly, F. (1967). Due to circumstances beyond our control. New York: Random House.

Gans, H. (1970). The mass media as an educational institution. In Pappas, G., (Ed.), Concepts in art education, London: Macmillan. Greenberg, B., Simmons, K., Hogan, L., Atkin, C. (1980). The demography of fictional tv characters. In Greenberg, B. (Ed.)

Life on television: content analyses of U.S. tv drama. Norwood: Ablex.

Gross, L. (1974). The real world of television. Today's Education, 63 (1), 86-92.

Hiebert, R. and Reuss, C. (Eds.), (1985). Impact of mass media. White 
Plains, New York: Longman.

Hospers, J. (1978). Artistic criticism. Reason, 10, (1), 295-335.

Mander, J. (1977). Four arguments for the eliminaton of television.

New York: Morrow Quill Paperbacks.

Lanier, V. (1968). The image of the artist in fictional cinema.

Washington, D.C.: United States Office of Education, Department of Health, Education and Welfare.

Lanier, V. (1982). The arts we see. New York: Teachers College Press.

Nielsen, A. (1985). Nielsen report on television. Northbrook:

Nielsen Media Research.

Novak, M. (1982). Television shapes the soul. In Richard P. Adler

(Ed.) Understanding television. New York: Praeger.

Real, M. (1977). Mass-mediated culture. Englewood Cliffs, N J:

Prentice-Hall.

Rose, B. (Ed.), (1985). TV genre: a handbook and reference guide.

Westport, Conn: Greenwood Press.

Schiller, H. (1973). The mind managers. Boston: Beacon Press.

Wilenski, H. (1964). Mass society and mass culture: interdependence or dependence? American Sociological Review, 29 (2), 173-197. 